Abstracted/indexed in Academic Search Complete, Agroforestry Abstracts, Asia Journals Online, Bangladesh Journals Online, Biological Abstracts, BIOSIS Previews, CAB Abstracts, Current Abstracts, Directory of Open Access Journals, EMBASE/Excerpta Medica, Google Scholar, HINARI (WHO), International Pharmaceutical Abstracts, Open J-gate, Science Citation Index Expanded, SCOPUS and Social Sciences Citation Index; ISSN: 1991-0088

\title{
Resveratrol overcomes TRAIL resistance in human colon cancer cells
}

\author{
Xiao-Bing Li'1, Yun-Gang Deng², Jia-Ping Huㄹ, Zhi Wang4, Rong-Zhen Xie ${ }^{2}$, Hong Luo5 and \\ Xiao-Yun $\mathrm{Hu}^{6}$
}

${ }^{1}$ Department of Oncology, Xinyu People's Hospital, P.R. China; 2Department of Stomach Enterochirurgia Gastrointestinal Surgery, The First Affiliated Hospital of Gannan Medical University, P.R. China; ${ }^{3}$ Department of General Five, The First Affiliated Hospital of Nanchang University, P.R. China; ${ }^{4}$ Department of Oncology, Jiujiang First People's Hospital, P.R. China; ${ }^{5}$ Department of Oncology, Jiangxi Shangrao People's Hospital, P.R. China; ${ }^{6}$ Department of General surgery, The $2 n d$ Affiliated Hospital of Nanchang University, P.R. China.

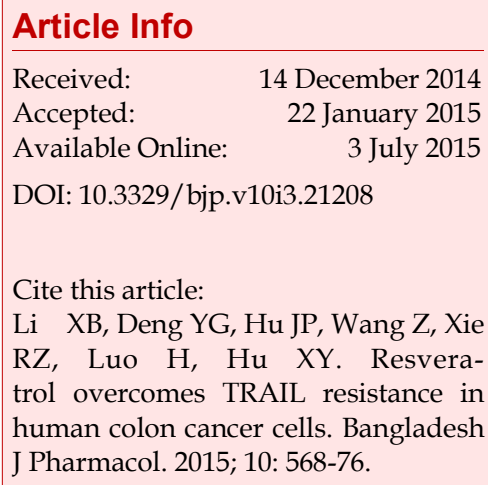

\begin{abstract}
Resveratrol is a stilbenoid compound, and a promising potent chemopreventive bioactive agent. Here, we showed for the first time that the combined treatment with resveratrol and TRAIL drastically induced apoptosis in human colon cancer cells when compared to single treatments. Further, resveratrol markedly up-regulated TRAIL receptors, DR5 and DR4 and the results revealed that DR5 siRNA efficiently blocked apoptosis induced by the co-treatment with resveratrol and TRAIL, indicating that DR5 up-regulation by resveratrol helps to enhance TRAIL actions. In addition, the combined effect was tested on normal human cells. All the obtained results suggested that resveratrol is very useful for TRAIL-based treatments for cancer.
\end{abstract}

\section{Introduction}

Resveratrol (RSV, 3,5,4'-trihydroxy-trans-stilbene), (Figure 1) a stilbenoid and a potent chemopreventive bioactive compound, is found in the skin of red grapes, and peanuts. It exerts anti-cancer properties by inhibi-

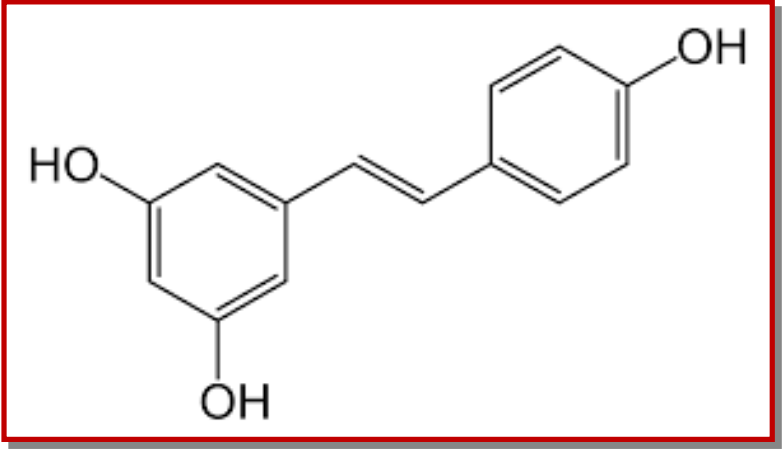

Figure 1: The structure of resveratrol ting three major stages of carcinogenesis, namely tumor initiation, promotion and progression (Jang et al., 1997). It was reported previously that resveratrol suppressed colon cancer cell proliferation and induced apoptosis even in the presence of IGF-1, a well-known growth factor elevated during obesity which has shown to enrich colon cancer stem cell populations (Vanamala et al., 2010; Hart et al., 2011). Resveratrol targets p53 and IGF-1R/Wnt signaling pathways to suppress colon cancer cell proliferation and induces apoptosis. Its interactions with p53, Akt and other effector proteins that regulate proliferation and apoptosis are well documented (Kim et al., 2006; Kuo et al., 2002; Kuwajerwala et al., 2002; Lin et al., 2008). Resveratrol has shown cardioprotective effect either in vitro or in vivo studies (Chen et al., 2013; Do et al., 2008; Lamont et al., 2011). Recently, as a natural polyphenol, the potential anticancer effect of resveratrol has attracted considerable attention. It is shown to prevent a variety of cancers, 
including liver, breast, oral cavity, esophagus, colon, as well as pancreatic cancer (Liao et al., 2010; Nakagawa et al., 2010; Shan et al., 2014; Zhou et al., 2003; Miki et al., 2012; Cho et al., 2012). However, the molecular mechanisms behind its anticancer effect are not completely understood.

Colon cancer is one of the types of cancer with the highest mortality rate in the United States and has been ranked the third most common cause of cancer mortality (Jemal et al., 2010). Moreover, an increase in the colon cancer incidence in adults under 50 years of age has been reported (Siegel et al., 2009). Colorectal cancer arises through a gradual series of well characterized histopathological changes, also known as the adenomacarcinoma sequence. 5-Fluorouracil was first introduced for the cure of $\mathrm{CRC}$, but its response rate is only $15 \%$ in metastatic colorectal cancer (Poon et al., 1989). Apoptosis can be initiated by two distinct pathways: one is the "intrinsic pathway" mediated by the mitochondria, and the other is the "extrinsic pathway" mediated by death receptors. Activation of those two pathways ultimately results in cleavage of caspase-3 and induction of apoptosis. Cross-talk between the extrinsic and intrinsic pathways has been observed mainly as an amplification loop at the level of execution of each cascade. Depending on the relative contribution of mitochondria in death receptor-mediated apoptosis, tumor cells can be classified as type I or type II cells (Igney and Krammer, 2002). Tumor necrosis factorrelated apoptosis-inducing ligand (TRAIL) is a member of the TNF superfamily and has attracted attention not only for its strong antitumor activity in a wide range of cancer cell types but also for its minimal cytotoxicity to most normal cells and tissues (Pitti et al., 1996). TRAIL, unlike Fas ligand, appears to preferentially induce apoptosis in tumor cells over normal cells. TRAIL binds to five distinct TRAIL receptors including death receptor 4 (TRAIL-R1) (Pan et al., 1997), KILLER/ DR5 (TRAIL-R2, TRICK2) (Pan et al., 1977; Wu et al., 1977; Walczak et al., 1997), DcR1 (TRID, TRAIL-R3) (Sheridan et al., 1997), DcR2 (TRUNDD OR TRAIL-R4) (Pan et al., 1998), and osteoprotegerin (Emery et al., 1998).These receptors have been classified into two groups, death-inducing receptors (TRAIL-R1 and -R2) and death-inhibitory receptors (TRAIL-R3, TRAIL-R4, and osteoprotegerin). Both TRAIL-R1 and TRAIL-R2 contain a Cterminal death domain that signals down-stream caspase activation to mediate TRAIL induced apoptotic cell death in a variety of tumor cell types.

The emergence of new Chinese medicine monomer anti -cancer drugs has provided a new option to the reptoire of synthetic drugs for cancer treatment (Xu et al., 2008). Cancer chemoprevention has been reported to be a promising strategy to prevent cancer death, particularly in colon cancer, due to the relatively slow progression of the colorectal adenomatous polyps in colon cancer, which enhances the opportunity for chemoprevention treatment. Results from epidemiological studies have associated fruit and vegetable consumption with a reduced risk of colon cancer, and various phytochemicals from commonly consumed fruit and vegetables have been identified as potential anti-cancer agents (De la Rosa et al., 2010). The present study aimed to investigate the anti-cancer effect of resveratrol in human colon cancer cells. To the best of our knowledge, the present study is the first study to demonstrate that resveratrol sensitizes cancer cells to TRAIL-induced apoptosis and overcomes its resistance in colon cancer cells.

\section{Materials and Methods}

\section{Reagents}

Resveratrol was purchased from Sigma- Aldrich (St. Louis, MO, USA). It was dissolved to a concentration of $50 \mathrm{mM}$ in $100 \%$ dimethyl sulfoxide (DMSO) as a stock solution and stored at $-20^{\circ} \mathrm{C}$. Soluble recombinant human TRAIL/Apo2L was purchased from Cell Signaling Technology, Inc. (Beverly, MA, USA). Human recombinant DR5 (TRAIL-R2)/Fc chimera protein and caspases inhibitors and $\mathrm{zVAD}$-fmk were purchased from R\&D Systems San Francisco, CA, USA).

\section{Cell culture}

Human colon cancer cells were purchased from American Type Culture Collection (Rockville, MD, USA) and maintained in Dulbecco's modified Eagle's medium (DMEM) supplemented with $10 \%$ fetal bovine serum, $4 \mathrm{mM}$ glutamine, $100 \mathrm{U} / \mathrm{mL}$ penicillin, and 100 $\mu \mathrm{g} / \mathrm{mL}$ streptomycin). Cells were incubated at $37^{\circ} \mathrm{C}$ in a humidified atmosphere of $5 \% \quad \mathrm{CO}_{2}$. Human colon cancer DLD-1 and prostate cancer PC3 cells were maintained in RPMI-1640 Medium supplemented with $10 \%$ fetal bovine serum, $2 \mathrm{mM}$ glutamine, $100 \mathrm{U} / \mathrm{mL}$ penicillin, and $100 \mu \mathrm{g} / \mathrm{mL}$ streptomycin. Normal human peripheral blood mononuclear cells were prepared as described previously (Nakata et al., 2004). Normal human hepatocytes were obtained from Cell Systems (Kirkland, WA, USA).

\section{Annexin V/propidium iodide (PI) double staining}

Apoptotic cells were quantified using an Annexin $\mathrm{V}$-fluorescein isothiocyanate (FITC)/PI kit (BD Biosciences, San Jose, CA, USA) and detected using flow cytometry using a FACSCalibur ${ }^{\mathrm{TM}}$ flow cytometer (Becton, Dickinson and Company, Franklin Lakes, NJ, USA) and analyzed using Modfit and CellQuest ${ }^{\mathrm{TM}}$ software (Becton, Dickinson and Company). In brief, cells were pretreated with $40 \mu \mathrm{M}$ resveratrol for $24 \mathrm{~h}$ and washed with phosphate-buffered saline (PBS). Cells were then collected and resuspended in binding buffer [10 mM 4-(2-hydroxyethyl)-1-piperazine ethane sulfonic acid ( $\mathrm{pH} 7.5), 2.5 \mathrm{mM} \mathrm{CaCl}_{2}$ and $140 \mathrm{mM} \mathrm{NaCl}$ ). 
Cells were incubated with Annexin V-fluorescein isothiocyanate and PI for 15 min in the dark, prior to flow cytometric analysis. Annexin V-positive cells were considered to be in the early stage of apoptosis, whereas annexin V and PI-positive cells were considered to be in the late stage of apoptosis.

\section{Western blot analysis}

Cells were washed once with phosphate-buffered saline and lysed with 100-150 mL of sodium dodecyl sulfate (SDS) buffer (50 mM Tris- $\mathrm{HCl}, \mathrm{pH} 7.5,1 \%$ SDS, $0.5 \mathrm{mM}$ PMSF, $2 \mathrm{mg} / \mathrm{mL}$ aprotinin, $2 \mathrm{mg} / \mathrm{mL}$ leupeptin, and 1 mM DTT). The whole-cell extracts were electrophoresed with 10-12.5\% SDS-polyacrylamide gels and transferred onto a polyvinylidene difluoride (PVDF) membrane (Milli-pore, Bedford, MA, USA). Rabbit polyclonal anti-DR5 and DR4 (Prosci, Poway, CA), BclXL (Santa Cruz, Santa Cruz, CA) and survivin (R\&D systems) antibodies and mouse monoclonal anticaspase-8 (MBL, Nagoya, Japan), pro-caspase-3 (Immunotech, Marseile, France), PARP (Santa Cruz), Xlinked inhibitor of apoptosis protein (XIAP) (R\&D systems) and $\beta$-actin (Sigma) antibodies were used as the primary antibodies. The signal was then developed with the enhanced chemiluminescence system (ECL, Amersham Pharmacia Biotech, Piscataway, NJ, USA).

\section{siRNAs}

The DR5 and LacZ siRNA sequences used were previously described (Wang and Deiry, 2004), and DR4 siRNA sequences used were previously described (Ren et al., 2004), where LacZ siRNA was used as a siRNA control. In brief, 1 day prior to transfection, cells were seeded without antibiotics to a density of 30$40 \%$. DR5, DR4 and LacZ siRNA (1 nM in HeLa, $10 \mathrm{nM}$ in DU145) were transfected into cells using a modified oligo-fectamine protocol (Invitrogen, Carlsbad, CA, USA), for which the volume of oligofectamine was reduced to one-third the recommended volume to limit toxic effects. After 24 hours, the cells were treated with $40 \mu \mathrm{M}$ resveratrol for 24 hours and then harvested.

\section{Statistical analysis}

Data represent means \pm SD for triplicate experiments and were analyzed using Student's t-test. Differences were considered significant from controls when $p<0.05$.

\section{Results and Discussion}

Figure 2a shows the effect of resveratrol on apoptosis in Caco colon cancer cells. Results show that treatment with resveratrol did not induce apoptosis in Caco cells. TRAIL induced weak apoptosis in Caco cells as a single agent. Later, we examined the combined effect of resveratrol and TRAIL on apoptosis. It is found that the combined treatment drastically induced apoptosis in a resveratrol dose-dependent manner. We employed caspase inhibitors, in order to confirm that the sub-G1 population represents apoptosis triggered through caspases (Figure 2b). Combined treatment proved that pan-caspase inhibitor and specific caspase-3, and -8 inhibitors effectively blocked the apoptosis and this indicating that resveratrol sensitizes Caco cells to TRAIL-induced apoptosis in acaspase-dependent manner. In addition, a dominant negative form of the TRAIL receptor, DR5/ Fc chimeric protein, also blocked apoptosis by the combined treatment (Figure 2c). All these results indicate that resveratrol enhances TRAIL actions through the interaction of TRAIL and TRAIL receptors.

Nuclei were examined after DAPI staining (Figure 3a). The nuclei in cells treated with resveratrol or TRAIL were similar to those in cells treated with the DMSO whereas the combined effect of resveratrol and TRAIL induced nuclear fragmentation and condensation that are the characteristics of apoptotic cells. Caspases investigation was also carried out. It is known that Poly (ADP-ribose) polymerase (PARP) is a substrate of caspases and is cleaved by caspases in apoptotic cells (Lazebnik et al., 1994). The cleaved PARP can be used as a marker of apoptosis. Figure $3 \mathrm{~b}$ shows the western blotting of PARP in Caco cells treated with resveratrol and/or TRAIL. The combined effect results in PARP cleavage whereas treatment with resveratrol or TRAIL failed to show. All these results clearly indicated that combined treatment of resveratrol and TRAIL results in drastic apoptosis and can be correlated with the results in Figure 2 and Figure 3A. In addition, the cleavage of caspases was also examined, since caspases are activated by cleavage and resulting in apoptosis. Figure 3B shows that caspase-3, and -8 were clearly cleaved upon combined treatment when compared with single treatments of resveratrol and TRAIL. Figure 3 indicated that the pan-caspase inhibitor $\mathrm{zVAD}$ blocked the cleavage of PARP and caspases by the combined effect.

In order to examine the molecular mechanism underlying the enhancement of TRAIL-induced apoptosis by resveratrol, we studied the TRAIL receptors expression. Resveratrol increased the DR5 and DR4 protein level in a dose-dependent manner (Figure 4a). Literature reports showed that XIAP and survivin are capable of modulating sensitivity to TRAIL in cancer cells (Zhang and Fang, 2005) and hence, we studied the XIAP and survivin expressions in resveratrol-treated cells, but it was found that there obtained no changes in the levels (Figure 4b). Bcl-2 family proteins $\mathrm{Bcl}-2, \mathrm{Bcl}-\mathrm{XL}$, and $\mathrm{Bax}$, possess the tendency to regu-late TRAIL-induced apoptosis (LeBlanc et al., 2002). The results shown in Figure $4 \mathrm{~b}$ indicated that resveratrol did not significantly change Bcl-XL and Bax protein levels. Conversely, Bcl-2 protein was found to rise by resveratrol treatment. These results indicate that the 


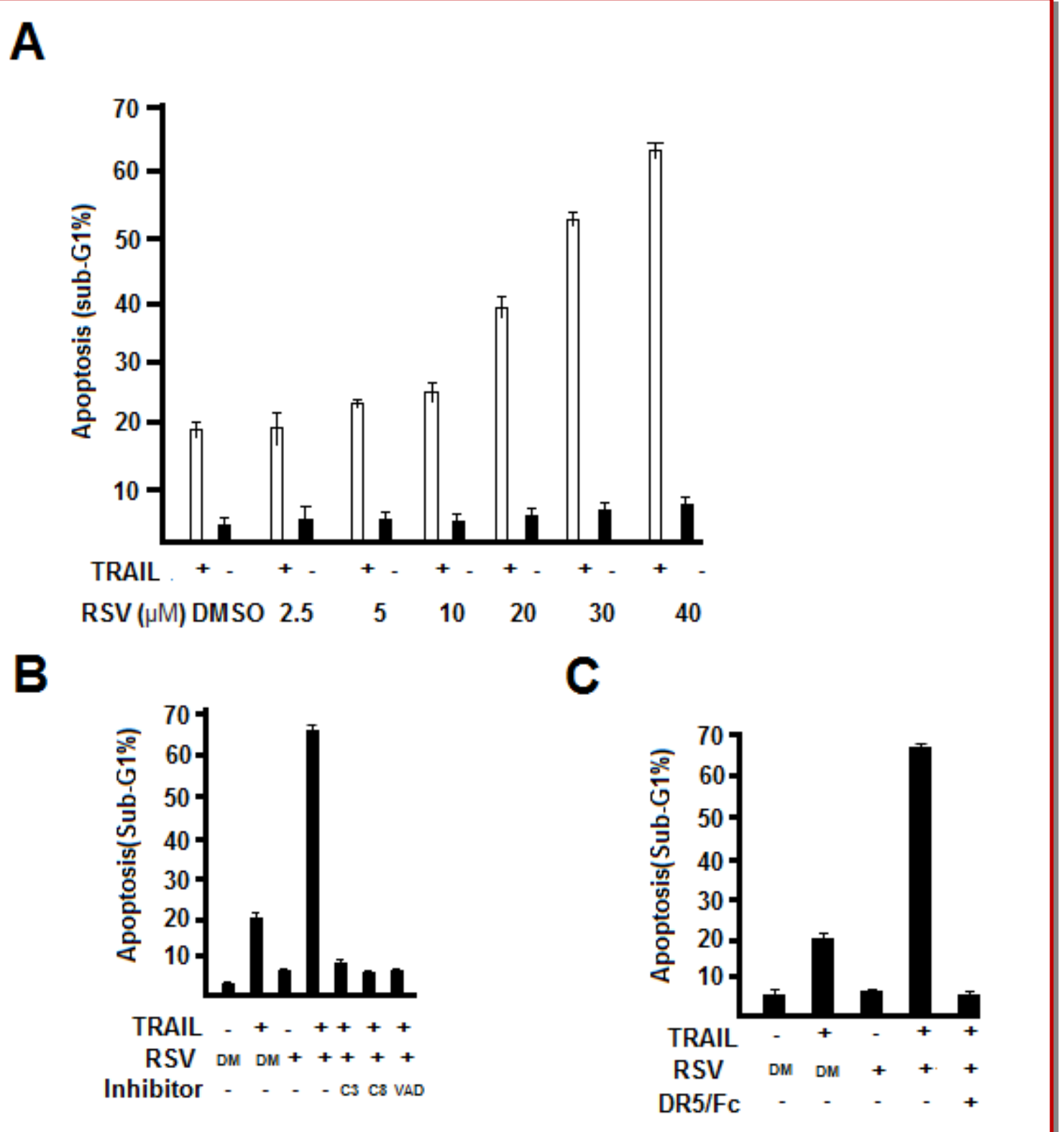

Figure 2: Resveratrol sensitizes Caco cells to TRAIL-induced apoptosis. (A) Caco cells with $50 \mathrm{ng} / \mathrm{mL}$ TRAIL and the indicated concentrations of resveratrol for 24 hours. (B) Caco cells were cultured in the presence or absence of $20 \mathrm{ng} / \mathrm{mL}$ TRAIL and/or 40 $\mu \mathrm{M}$ resveratrol with or without $20 \mu \mathrm{M}$ of the caspase inhibitors. (C) Cells were treated as shown in (B) with or without $1 \mu \mathrm{g} / \mathrm{mL}$ of DR5/Fc protein. The values shown are means $(\mathrm{n}=3)$; bars, $\pm \mathrm{SD}$

results indicate that the up-regulation of DR5 and DR4 proteins can be a key factor by which resveratrol sensitizes Caco cells to TRAIL-induced apoptosis.

To verify the knockdown efficiency, Western blotting was carried out after the siRNA and resveratrol treatments. We used siRNA to prevent the upregulation of DR5 and DR4 expression in order to examine whether DR5 and DR4 up-regulation by resveratrol contributes to the dramatic apoptosis induced by the combination of resveratrol and TRAIL. As shown in Figure 3c, promising results were obtained from western blotting and confirmed that DR5 and DR4 siRNAs could actually provoke the knockdown of target genes. The combined effect shows that DR5 effectively abrogated the apoptosis and not DR4 siRNA. In addition, the DR4 siRNA and DR5 siRNA together had a similar effect to DR5 siRNA alone. These results indicate that DR5 up-regulation by resveratrol plays an important role in the apoptosis induced by combined effect.

The combined treatmet of resveratrol and TRAIL were tested in other cancer cells in order to eliminate a 


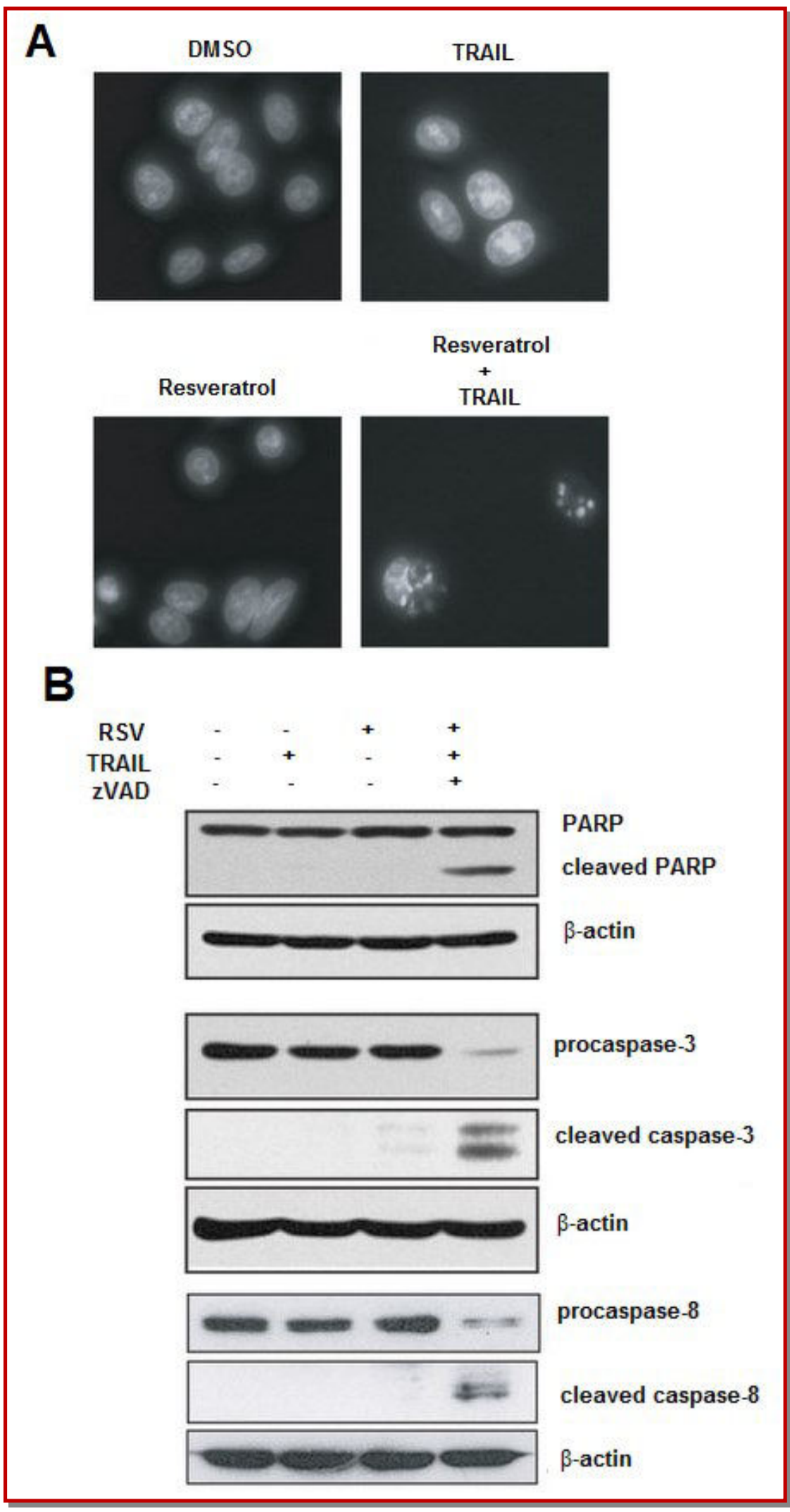

Figure 3: The combination of resveratrol and TRAIL induces nuclear condensation and fragmentation and cleaves caspases and a substrate of caspases PARP. (A) Nuclei in cells stained with DAPI. Caco cells were treated with $20 \mathrm{ng} / \mathrm{mL}$ of TRAIL and/or $40 \mu \mathrm{M}$ resveratrol. (B) Western blotting of PARP, caspase-3, and -8. $\beta$-actin is a loading control. (-, no treatment; DM, solvent DMSO treatment) 


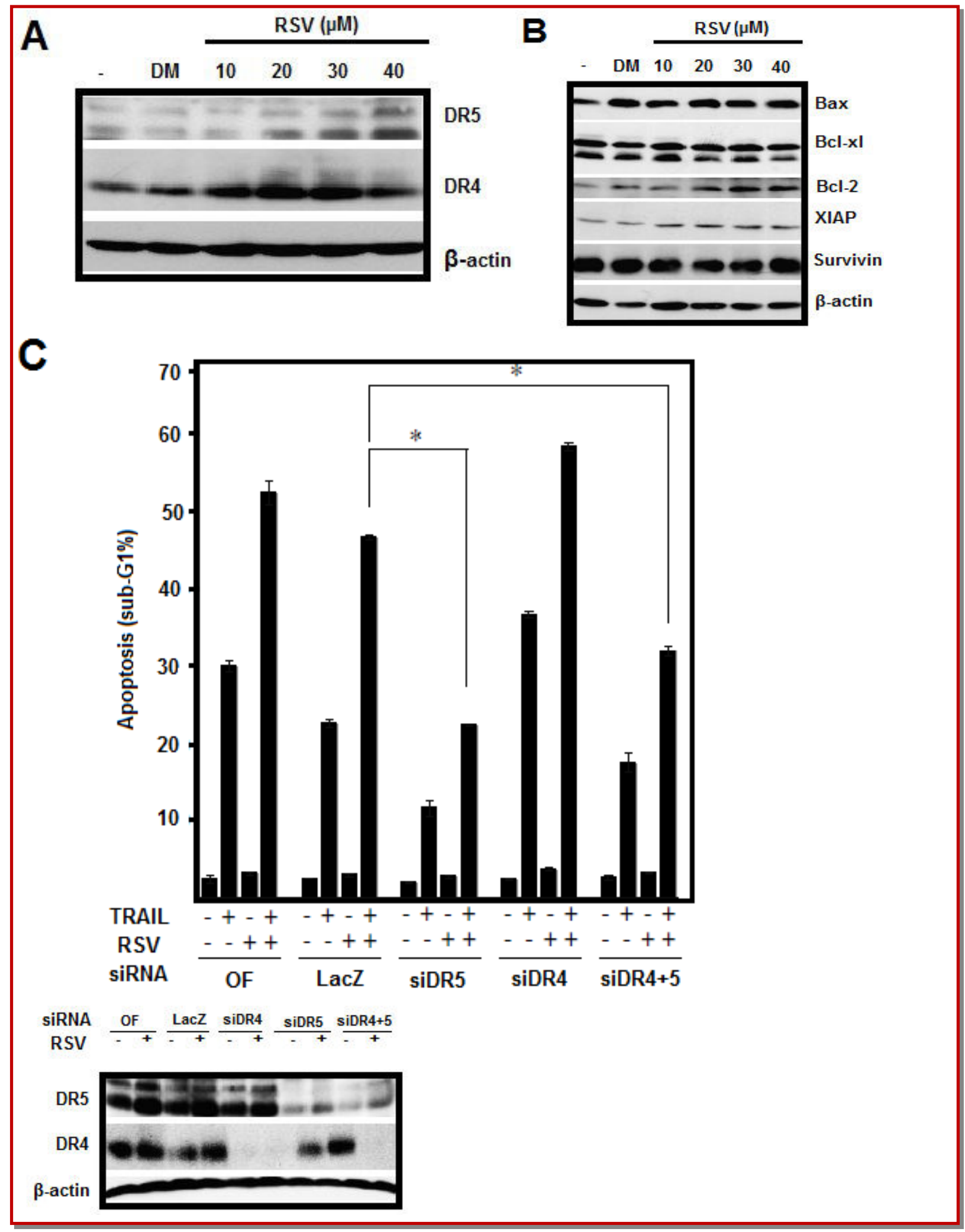

Figure 4: (A) Western blotting of DR5 and DR4. Caco cells were treated with the indicated concentrations of resveratrol for 24 hours. $\beta$-actin is a loading control. (B) Western blotting of XIAP, survivin and bcl-2 family proteins. - , no treatment; DM, solvent DMSO treatment. (C) Caco cells were transfected with DR5, DR4 or control LacZ siRNA (40 nM). Twenty-four hours after transfection, cells were treated with $20 \mathrm{ng} / \mathrm{mL}$ of TRAIL and/or $40 \mu \mathrm{M}$ resveratrol for 24 hours. The values shown are means ( $\mathrm{n}=3$ ); bars $\pm \mathrm{SD} ;{ }^{*} \mathrm{p}<0.05$ 


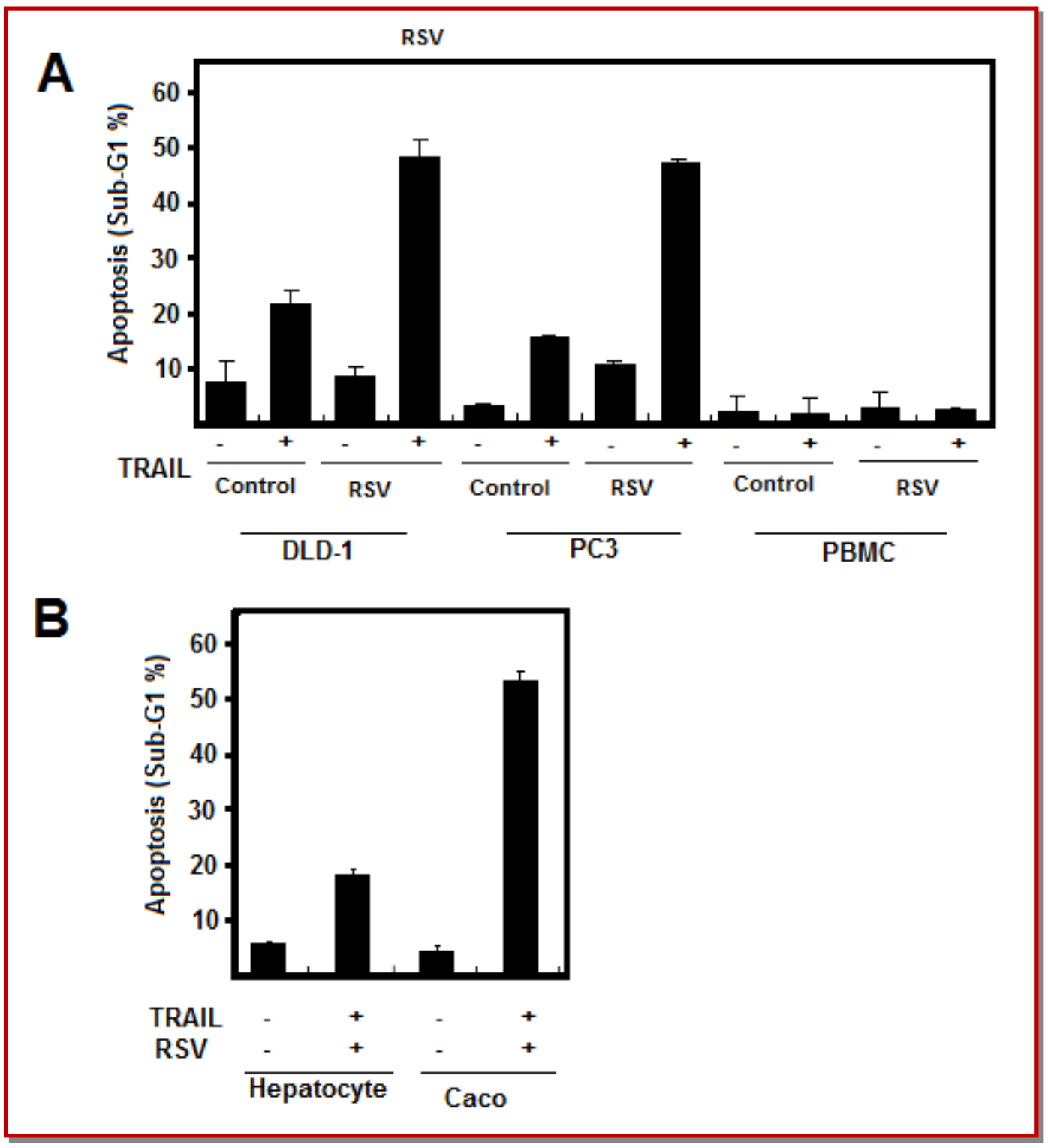

Figure 5: (A) Human colon cancer DLD-1 cells, prostate cancer PC3 cells and PBMC cells were treated with $40 \mu \mathrm{M}$ resveratrol and/or $5 \mathrm{ng} / \mathrm{mL}$ of TRAIL for 24 hours. (B) Normal human hepatocytes and colon cancer Caco cells were treated as shown in (A). The values shown are means $(n=3)$; bars, $\pm S D$

possibility that the combined effect in a Caco cells is specific manner. Resveratrol enhanced TRAIL-induced apoptosis in human colon cancer DLD-1and prostate cancer PC3 cells as well as in Caco cells (Figure 5a). Apoptosis inducing is an effective way to eliminate cancer, however it will lead to cell death in normal tissues. It is a known fact that TRAIL is a promising candidate since it induces apoptosis in cancer cells but not normal cells (Walczak et al., 1999; Ashkenazi et al., 1999). Hence, enhancing TRAIL efficacy with resveratrol is also expected to have little toxic effect in normal cell lines. Thus, peripheral blood mononuclear cells (PBMC) were treated with resveratrol and/or TRAIL (Figure 5a). The combined effect did not induce apoptosis in PBMC. To eliminate the possibility that resveratrol enhances TRAIL-induced apoptosis in normal human hepatocytes as well as colon cancer Caco cells, we examined the combined effect on human heaptocytes. The combination caused very little apoptosis in normal human hepatocytes compared with colon cancer Caco cells (Figure 5b).

In conclusion, these results showed here that a stilbenoid, resveratrol, sensitizes colon cancer cells to TRAILinduced apoptosis due to the induction of DR5. Furthermore, we proved that the combined effect of resveratrol and TRAIL had little cytotoxic effects in normal cells in comparison with colon cancer Caco cells. These results suggest that the combination of TRAIL with resveratrol is a useful strategy of cancer therapeutics. 


\section{References}

Ashkenazi A, Pai RC, Fong S, Leung S, Lawrence DA, Marsters SA, Blackie C, Chang L, McMurtrey AE, Hebert A, DeForge L, Koumenis IL, Lewis D, Harris L, Bussiere J, Koeppen H, Shahrokh Z, Schwall RH. Safety and antitumor activity of recombinant soluble Apo2 ligand. J Clin Invest. 1999; 104: $155-62$.

Chen CJ, Fu YC, Yu W, Wang W. SIRT3 protects cardiomyocytes from oxidative stress-mediated cell death by activating NF-kB. Biochem Biophys Res Commun. 2013; 430: 798-03.

Cho IR, Koh SS, Malilas W, Srisuttee R, Moon J, Choi YW, Horio Y, Oh S, Chung YH. SIRT1 inhibits proliferation of pancreatic cancer cells expressing pancreatic adenocarcinoma upregulated factor (PAUF), a novel oncogene, by suppression of $\beta$-catenin. Biochem Biophys Res Commun. 2012; 423: 270-75.

De la Rosa L, Alvarez-Parrilla E, González-Aguilar GA. Fruit and vegetable phytochemicals: Chemistry, nutritional value and stability. In: Phenolic compounds: Chemistry and occurrence in fruits and vegetables. Wiley-Blackwell, EUA, 2010, pp 53-88.

Do GM, Kwon EY, Kim HJ, Jeon SM, Ha TY, Park T, Choi MS. Long-term effects of resveratrol supplementation on suppression of atherogenic lesion formation and cholesterol synthesis in apo E-deficient mice. Biochem Biophys Res Commun. 2008; 374: 55-59.

Emery JG, McDonnell P, Burke MB, Deen KC, Lyn S, Silverman C, Dul E, Appelbaum ER, Eichman, C, DiPrinzio R, Dodds RA, James IE, Rosenberg M, Lee JC, Young PR. Osteoprotegrein is a receptor for the cytotoxic ligand TRAIL. J Biol Chem. 1998; 273: 14363-67.

Hart LS, Dolloff NG, Dicker DT, Koumenis C, Christensen JG, Grimberg A, El- Deiry WS. Human colon cancer stem cells are enriched by insulin-like growth factor- 1 and are sensitive to figitumumab. Cell Cycle 2011; 10: 2331-38.

Igney FH, Krammer PH. Death and anti-death: Tumour resistance to apoptosis. Nat Rev Cancer. 2002; 2: 277-88.

Jang M, Cai L, Udeani GO, Slowing KV, Thomas CF, Beecher CW, Fong HH, Farnsworth NR, Kinghorn AD, Mehta RG, Moon RC, Pezzuto JM. Cancer chemopreventive activity of resveratrol, a natural product derived from grapes. Science 1997; 275: 218-20.

Jemal A, Siegel R, Xu J, Ward E. Cancer statistics. CA Cancer J Clin. 2010; 60: 277-00.

Kim AL, Zhu Y, Zhu H, Han L, Kopelovich L, Bickers DR, Athar M. Resveratrol inhibits proliferation of human epidermoid carcinoma A431 cells by modulating MEK1 and AP-1 signalling pathways. Exp. Dermatol. 2006; 15: 538-46.

Kuo PL, Chiang LC, Lin CC. Resveratrol-induced apoptosis is mediated by p53-dependent pathway in Hep G2 cells. Life Sci. 2002; 72: 23-34.

Kuwajerwala N, Cifuentes E, Gautam S, Menon M, Barrack ER, Reddy GP. Resveratrol induces prostate cancer cell entry into s phase and inhibits DNA synthesis. Cancer Res. 2002; 62: 2488-92.

Lamont KT, Somers S, Lacerda L, Opie LH, Lecour S. Is red wine a SAFE sip away from cardioprotection? Mechanisms involved in resveratrol-and melatonin-induced cardioprotection. J Pineal Res. 2011; 50: 374-80.

Lazebnik YA, Kaufmann SH, Desnoyers S, Poirier GG, Earnshaw WC, Cleavage of poly(ADP-ribose)polymerase by a proteinase with properties like ICE. Nature 1994; 371: 34647.

LeBlanc H, Lawrence D, Varfolomeev E, Totpal K, Morlan J, Schow P, Fong S, Schwall R, Sinicropi D, Ashkenazi A. Tumor-cell resistance to death receptor-induced apoptosis through mutational inactivation of the proapoptotic Bcl-2 homolog Bax. Nat Med. 2002; 8: 274-81.

Liao PC, Ng LT, Lin LT, Richardson CD, Wang GH, Lin CC. Resveratrol arrests cell cycle and induces apoptosis in human hepatocellular carcinoma Huh-7 cells. J Med Food. 2010; 13: 1415-23.

Lin HY, Sun M, Tang HY, Simone TM, Wu YH, Grandis JR, Cao HJ, Davis PJ, Davis FB. Resveratrol causes COX-2- and p53-dependent apoptosis in head and neck squamous cell cancer cells. J Cell Biochem. 2008; 104: 2131-42.

Miki H, Uehara N, Kimura A, Sasaki T, Yuri T, Yoshizawa K, Tsubura A. Resveratrol induces apoptosis via ROS triggered autophagy in human colon cancer cells. Int J Oncol. 2012; 40: 1020-28.

Nakagawa H, Kiyozuka Y, Uemura Y, Senzaki H, Shikata N, Hioki K, Tsubura A. Resveratrol inhibits human breast cancer cell growth and may mitigate the effect of linoleic acid, a potent breast cancer cell stimulator. J Cancer Res Clin Oncol. 2010; 127: 258-64.

Nakata S, Yoshida T, Horinaka M, Shiraishi T, Wakada M, Sakai T. Histone deacetylase inhibitors up-regulate death receptor 5/TRAIL-R2 and sensitize apoptosis induced by TRAIL/APO2-L in human malignant tumor cells. Oncogene 2004; 23: 6261-71.

Pan G, Ni J, Wei YF, Yu G, Gentz R, Dixit VM. An antagonist decoy receptor and a death domain-containing receptor for TRAIL. Science 1977; 277: 815-18.

Pan G, Ni J, Yu G, Wei YF, Dixit VM. TRUNDD, a new member of the TRAIL receptor family that antagonizes TRAIL signaling. FEBS Lett. 1998; 424: 41-45.

Pan G, O’Rourke K, Chinnaiyan AM, Gentz R, Ebner R, Ni J, Dixit VM. The receptor of the cytotoxic ligand TRAIL. Science 1997; 276: 111-13.

Pitti RM, Marsters SA, Ruppert S, Donahue CJ, Moore A, Ashkenazi A. Induction of apoptosis by Apo-2 ligand, a new member of the tumor necrosis factor cytokine family. J Biol Chem. 1996; 271: 12687-90.

Poon MA, Oconnell MJ, Moertel CG, Wieand HS, Cullinan SA, Everson LK, Krook JE, Mailliard JA, Laurie JA, Tschetter LK. Biochemical modulation of fluorouracil: Evidence of significant improvementof survival and quality of life in patients with advanced colorectal carcinoma. J Clin Oncol. 1989; 7: 1407-18.

Ren YG, Wagner KW, Knee DA, Aza-Blanc P, Nasoff M, Deveraux QL. Differential regulation of the TRAIL death receptors DR4 and DR5 by the signal recognition particle. Mol Biol Cell. 2004; 11: 5064-74. 
Shan Z, Yang G, Xiang W, Pei-Jun W, Bin Z. Effects of resveratrol on oral squamous cell carcinoma (OSCC) cells in vitro. J Cancer Res Clin Oncol. 2014; 140: 371-74.

Sheridan JP, Marsters SA, Pitti RM, Gurney A, Skubatch M, Baldwin D, Ramakrishnan L, Gray CL, Baker K, Wood WI, Goddard AD, Godowski P, Ashkenazi, A. Control of TRAILinduced apoptosis by a family of signaling and decoy receptors. Science 1997; 277: 818-21.

Siegel RL, Jemal A, Ward EM. Increase in incidence of colorectal cancer among young men and women in the United States. Cancer Epidemiol Biomarkers Prev. 2009; 18: 1695-98.

Vanamala J, Reddivari L, Radhakrishnan S, Tarver C. Resveratrol suppresses IGF-1 induced human colon cancer cell proliferation and elevates apoptosis via suppression of IGF-1R/Wnt and activation of p53 signaling pathways. BMC Cancer 2010; 10: 238.

Walczak H, Degli-Esposti MA, Johnson RS, Smolak PJ, Waugh JY, Boiani N, Timour MS, Gerhart M J, Schooley KA, Smith CA, Goodwin RG, Rauch CT. TRAIL-R2: A novel apoptosismediating receptor for TRAIL. EMBO J. 1997; 16: 5386-97.

Walczak H, Miller RE, Ariail K, Gliniak B, Griffith TS, Kubin
M, Chin W, Jones J, Woodward A, Le T, Smith C, Smolak P, Goodwin RG, Rauch CT, Schuh JC, Lynch DH. Tumoricidal activity of tumor necrosis factor-related apoptosis-inducing ligand in vivo. Nat Med. 1999; 5: 157-63.

Wang S, El-Deiry WS. Inducible silencing of KILLER/DR5 in vivo promotes bioluminescent colon tumor xenograft growth and confers resistance to chemotherapeutic agent 5fluorouracil. Cancer Res. 2004; 64: 6666-72.

Wu GS, Burns TF, McDonald ER, Jiang W, Meng R, Krantz ID, Kao G, Gan DD, Zhou JY, Muschel R., Hamilton SR, Spinner NB, Markowitz S, Wu G, El-Deiry WS. KILLER/DR5 is a DNA damage-inducible p53-regulated death receptor gene. Nat Genet. 1997; 17: 141-43.

Xu TM, Cui MH, Xin Y, Gu LP, Jiang X, Su MM, Wang DD, Wang DJ. Inhibitory effect of ginsenoside Rg3 on ovarian cancer metastasis. Chin Med J. 2008; 121: 1394-97.

Zhang L, Fang B. Mechanisms of resistance to TRAIL-induced apoptosis in cancer. Cancer Gene Ther. 2005; 12: 228-37.

Zhou HB, Yan Y, Sun YN, Zhu JR. Resveratrol induces apoptosis in human esophageal carcinoma cells. World J Gastroenterol. 2003; 9: 408-11.

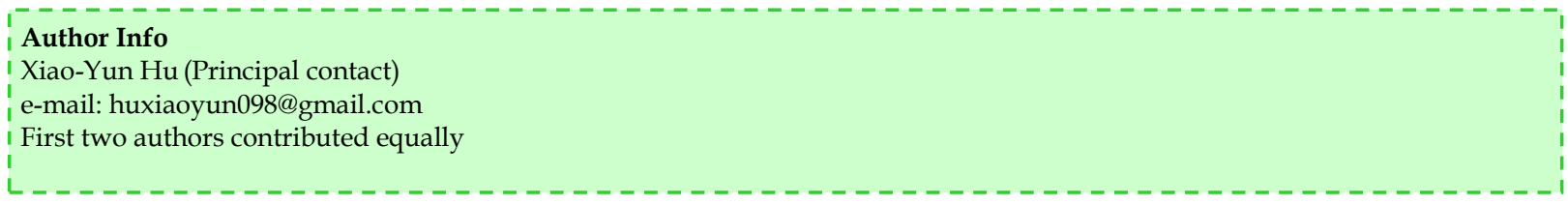

